\title{
Kraepelin digitised: new technologies for monitoring the course of bipolar disorder
}

\author{
Yanni Malliaris \\ From $1^{\text {st }}$ International Congress on Neurobiology and Clinical Psychopharmacology and European \\ Psychiatric Association Conference on Treatment Guidance \\ Thessaloniki, Greece. 19-22 November 2009
}

In this symposium we will present novel work on new technologies developed to facilitate the symptomatic monitoring of Bipolar disorder in the context of recent prospective studies (Judd et al. 2002, Post et al. 2003) that have investigated the subsyndromal and syndromal course of the disorder and have highlighted the chronicity, variability, and complex nature of Bipolar symptomatology. Emil Kraepelin's need to map his clinical observations and to gather data in order to carefully characterize the episodic course of manic depressive illness led him to develop the first graphical life-chart for Bipolar patients. Many decades later paper-based life charting systems were developed to monitor bipolar disorder, including the ChronoSheet by Peter Whybrow and the Life Chart Methodology (NIMH-LCM) by Robert Post. Over the last 10 years these paper methodologies have been computerized, and we now have a number of different systems to assist the electronic monitoring of Bipolar disorder. In this symposium two complementary electronic systems will be presented (Moodchart and iMonitor) along with a brief overview of the research they have generated. Finally, the symposium will conclude with novel and still experimental research using actigraphic devices for monitoring the course as well as the activities of bipolar patients.

Published: 22 April 2010

doi:10.1186/1744-859X-9-S1-S10

Cite this article as: Malliaris: Kraepelin digitised: new technologies for monitoring the course of bipolar disorder. Annals of General Psychiatry 2010 9(Suppl 1):S10.

Institute of Psychiatry, King's College London, UK
Submit your next manuscript to BioMed Central and take full advantage of:

- Convenient online submission

- Thorough peer review

- No space constraints or color figure charges

- Immediate publication on acceptance

- Inclusion in PubMed, CAS, Scopus and Google Scholar

- Research which is freely available for redistribution

Submit your manuscript at www.biomedcentral.com/submit
C Biomed Central 